\title{
Palm community transitions along a topographic gradient from floodplain to terra firme in the eastern Amazon
}

\author{
Rodolfo SALM ${ }^{1 *}$, Anderson PRATES ${ }^{1}$, Nadson RESSYÉ SIMÔES ${ }^{1}$, Lisa FEDER ${ }^{2}$ \\ 1 Universidade Federal do Pará, Faculdade de Ciências Biológicas. Rua Coronel José Porfírio, n² 2515, CEP 68372-040. Altamira, Pará, Brazil. \\ 2 Academy of Art University, Department of Liberal Arts. 451 Post Street, CA 94102, San Francisco, California, USA. \\ * Corresponding author: rodolfosalm@ufpa.br
}

\section{ABSTRACT}

Palms show clear niche segregation patterns along topographic gradients in tropical forests, with some species associated to terra firme and others to seasonally flooded areas. The aim of this study was to quantitatively describe the fine-scale spatial variation within a palm community, tracking the changes in species' abundance along environmental gradients associated with a perennial stream the eastern Amazon. The study of palm communities was based on 60 forest plots in which all adult palms were counted. We found a total of 566 palms in a community containing 11 species. Furthermore, we found a significant separation in the palm community between seasonally-flooded and terra firme forests. We found a gradient with various densities of the three most abundant palm species within the first $100 \mathrm{~m}$ away from the flooded area. Other species were located exclusively in the terra firme forest. The abundance of the six most common species were distributed in relation to humidity gradients from floodplains to terra firme, with palm distribution from the most flood-tolerant to the least floodtolerant palm species as follows: Euterpe oleracea, Attalea phalerata and Socratea exorrhiza (species with floodplain affinity), Astrocaryum gynacanthum, Astrocaryum aculeatum, Attalea maripa (species with terra firme affinity).

KEYWORDS: Amazon forest, fine-scale distribution, Xingu River

\section{Transições em uma comunidade de palmeiras ao longo de um gradiente topográfico de uma floresta inundável à Terra Firme na Amazônia Oriental}

\section{RESUMO}

Palmeiras apresentam padrões claros de segregação de nicho ao longo de gradientes topográficos, com algumas espécies associadas a florestas de terra firme e outras a áreas alagáveis. O objetivo desse estudo foi descrever quantitativamente as variaçóes em pequena escala dentro de uma comunidade de palmeiras, investigando as mudanças na abundância de espécies ao longo de gradientes ambientais associados com um igarapé perene na Amazônia Oriental. O estudo de comunidades de palmeiras foi baseado em 60 parcelas florestais em que todos os adultos de palmeiras foram contados. Encontramos um total de 566 palmeiras em uma comunidade contendo 11 espécies. Além disso, encontramos uma separação significativa na comunidade de palmeiras entre florestas sazonalmente inundadas e florestas de terra firme e um gradiente das densidades das três espécies mais abundantes, ao longo dos primeiros $100 \mathrm{~m}$ de distância da área alagada. A abundância das seis espécies mais comuns variou em relação ao gradiente de umidade das áreas alagáveis para a terra firme, com a distribuição das palmeiras da mais tolerante a alagamentos a menos tolerante a alagamentos da seguinte forma: Euterpe oleracea, Attalea phalerata, Socratea exorrhiza (espécies associadas a áreas alagadas), Astrocaryum gynacanthum, Astrocaryum aculeatum, Attalea maripa (espécies com afinidade por terra firme).

PALAVRAS-CHAVE: Floresta Amazônica, distribuição em pequena escala, Rio Xingu 


\section{INTRODUCTION}

The transitions in palm species composition along gradients from rivers, over floodplains into the terra firme are a commonly known phenomenon (Kahn 1987; Kahn and De Granville 1992; Eiserhardt et al. 2012). However, the behavior of individual species along such transitions is still poorly known. Despite the rapidly growing number of studies of tropical palm communities across the Americas, the vast majority is designed to sample a palm community in a single habitat like terra firme, floodplain forest, or swamp forest; and just a few studies attempted to quantify such transitions over a continuous gradient (Balslev et al. 2011). Furthermore, large areas of the Amazon lack a single palm community description (Balslev et al. 2010).

Early studies in French Guiana, based on palms sampled in floristic plots revealed the change in palm species abundance concomitant with a change in soil drainage along those topographic transitions (Kahn and De Granville 1992). Since then, few other studies also described such phenomena across Amazonian sites: in streams near Manaus (Kahn and Castro 1985), in the Tocantins River valley (Kahn 1987; Scariot et al. 1989) in upper Urucu river (Peres 1994), and in the middle Xingu (Salm et al. 2007).

Here, we investigate the spatial variation within a palm community, from a floodplain to terra firme along a topographic gradient in a poorly known area of the eastern Amazon. Indeed, our study site lies at the center of a circle with a radius of $300 \mathrm{~km}$ in eastern Amazonia which, according to Balslev et al. (2011), there is no other published description of a palm community. More than just filling this gap and extending the general knowledge about palm community transitions along hydrological gradients to a thus far unstudied region, the aim of this study is to contribute to the understanding of specific species behavior along such gradient.

\section{MATERIALS AND METHODS}

\section{Study Area}

We confined the study to a 1,035 ha terra firme forest remnant at the fringes of the city of Altamira, the $51^{\text {st }}$ Forest Infantry Battalion ( $\left.51^{\text {st }} \mathrm{BIS}\right)$ area $\left(3^{\circ} 11^{\prime} \mathrm{S}, 52^{\circ} 10^{\prime} \mathrm{W}\right)$, (Figure 1A, B). Total annual rainfall for the studied area is approximately $2,000 \mathrm{~mm}$, on average. Climatic patterns show two distinct seasons marked by heavy precipitation from January to May followed by four to five months of extremely low rainfall (less than $100 \mathrm{~mm}$ but frequently close to nil) (Lucas et al. 2009). Current deforestation rates are the highest in the Brazilian Amazon because of the presence of the Transamazon Highway (BR-230), and the megahydroelectric Belo Monte dam (Fearnside 2006), among other developments. When the $51^{\text {st }}$ BIS Forest Camp was created in Altamira in 1972, it consisted of a mosaic of mature and successional forests in different stages of regeneration. There were also a few isolated households alongside associated small crop fields and pastures. At that point, all occupants were removed from the area, allowing forest regeneration of the degraded areas to proceed to a point where it became difficult to define the limits of the primary and secondary vegetation.

\section{Field data collection}

We studied a palm community along topographic gradients that follow the $51^{\text {st }}$ BIS stream, a relatively narrow, third order tributary of the Xingu River (1-3 m wide). The stream borders a floodplain that spans from a few meters to tens of meters wide along the riverbanks (Figure 1A, B). These seasonal floodplains contain highly organic hydromorphic soil. The floodplains are surrounded by moderately to highly steep hills with well-drained soils (hereafter referred to as terra firme).

Only adult palms were considered in this study. The palms were identified in the field with the assistance of the guide "Flora Brasileira - Arecaceae (Palmeiras)", and its nomenclature were used accordingly (Lorenzi et al. 2010). Due to the morphological diversity of palms, arbitrary criteria were used to assign individuals of different species to an adult class, following methodology applied by Salm et al. (2007). First, among those species that develop a subterranean stem (a stem that emerges to the surface at its approximated adult size diameter, like Attalea maripa or Astrocaryum aculeatum), the individual palms with an external and visible stem or with signs of present or past reproductive activity were considered adults. Secondly, the non-clonal arborescent palms whose stems thicken to its adult size after it emerges to the surface (like Oenocarpus distichus or Socratea exorrhiza) were considered adults when DBH was $\geq 5 \mathrm{~cm}$. Finally, among abundant clonal species (like Astrocaryum gynacanthum or Euterpe oleracea), we counted those genets that revealed signs of reproductive activity as adults, and each clump as one individual. We did not find any climbing palm (Desmoncus $s p$.) within our sampled area or any adult individual belonging to the group of small understory palms. Except for one cluster of few young Geonoma sp., and therefore not included in the collected data set. We also quantified the forest structure by measuring all trees (except palm trees) with diameter at breast height (DBH, measured at $1.37 \mathrm{~m}$ above ground) $\geq 10 \mathrm{~cm}$, in plots distributed according to two complementary approaches that used random and systematic sampling approaches, described below.

\section{Systematic sampling approach}

In the dry season of 2010, we distributed 20 plots of $0.2-$ ha $(200 \times 10 \mathrm{~m})$, along the $51^{\text {st }}$ BIS stream. Plots were drawn every $50 \mathrm{~m}$, from the spring (more or less in the middle of 


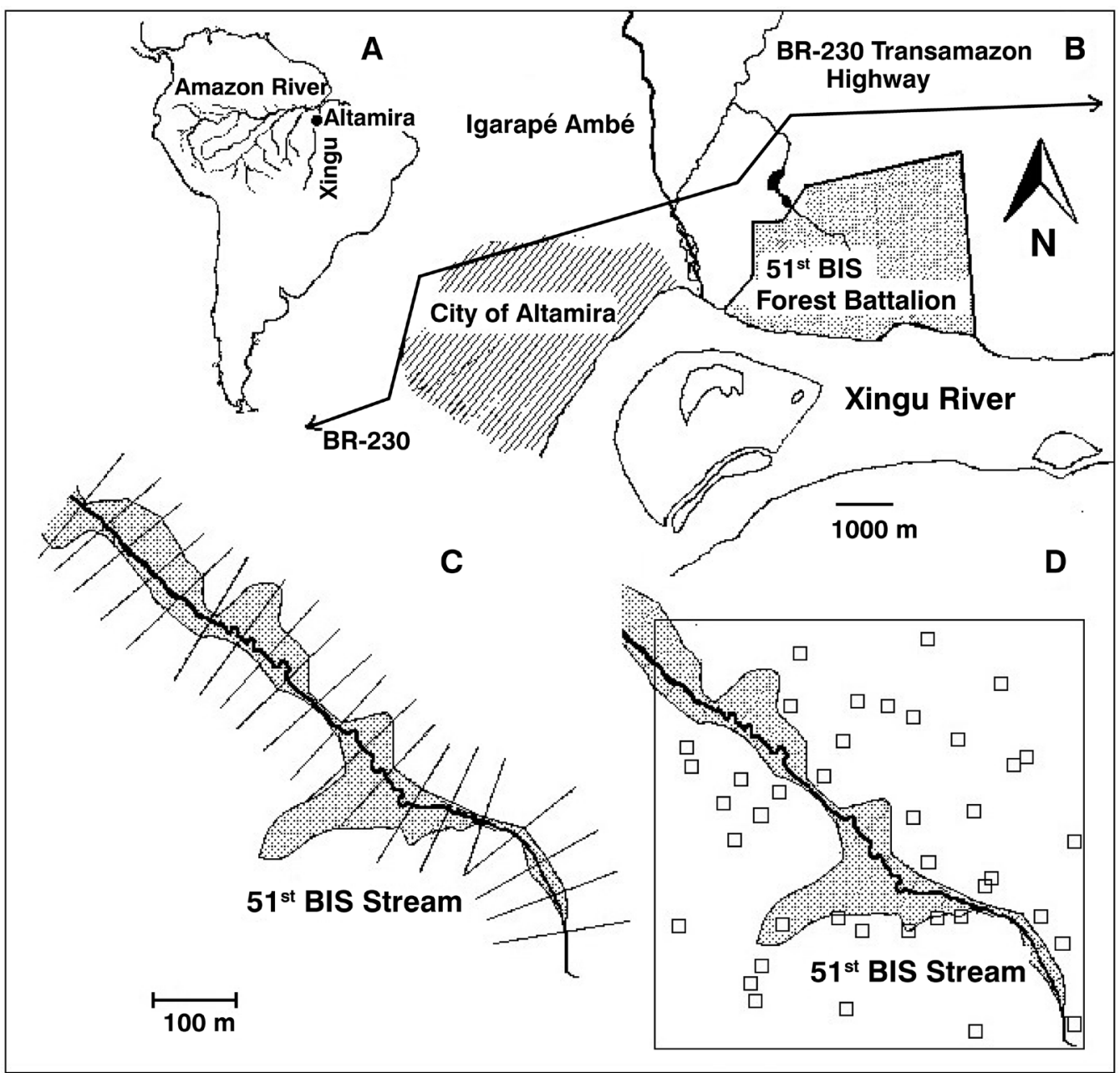

Figure 1. The study set up. A: Within the map of South America, the position of the city of Altamira, in the margin of the Xingu River, a major tributary of the right margin of the Amazon. B: The 1,035-ha area of the $51^{\text {st }}$ Jungle Infantry Battalion Forest Camp (51 $\left.1^{\text {st }} \mathrm{BIS}\right)$ in the margin of the Xingu River, close to the city of Altamira, and to the Transamazon highway (BR-230), crossed by the studied perennial stream. C: The random sampling approach with 40 plots of $625 \mathrm{~m}^{2}$ $(25 \times 25 \mathrm{~m})$ randomly disposed at a $500 \times 500 \mathrm{~m}$ square centered at the $51^{\mathrm{st}}$ BIS stream. D: The Regular sampling approach with 20 transects $(200 \times 10 \mathrm{~m})$ centered at the studied perennial stream, every $50 \mathrm{~m}$, from its source, approximately $1 \mathrm{~km}$ in length, to the point where the river leaves the area legally protected by the Brazilian army.

the protected area), perpendicularly from the stream axis out to the edge of the forest protected by the Forest Infantry Battalion (Figure 1C). As they were not parallel and the plots were not far from one another, the plots grew closer to one another at their extreme points, almost to the point of overlapping. By establishing such a design we were aware of the disadvantages of a considerable level of auto-correlation, but nevertheless proceeded as such due to the relatively small track of protected stream (roughly only $1 \mathrm{~km}$ ) and the large plot area required to sample the rarer palms. Within the plots, we identified and counted all adult palms, and we characterized the forest structure by measuring all non-palm trees with $\mathrm{DBH} \geq 10$ $\mathrm{cm}$. For data analysis, the $200 \mathrm{~m}$ long plots were divided in twenty 10 x $10 \mathrm{~m}$ subplots. These subplots were divided into two groups, the first corresponding to those areas subjected to seasonal flooding and the second, corresponding to terra firme. The floodplains in the flat and low terrain that surround the river are easily distinguishable from the terra firme forests on hill-slopes, as an abrupt waterline transition separates these areas. We used the non-parametric Spearman correlations to investigate the relationship between palms densities and their distance to floodplains. Since all transects departing from the stream were $100 \mathrm{~m}$ long and the floodplains that surround it have varied widths, we ended up with unbalanced data distribution, where closer plots to floodplains were more abundant than the distant ones. 


\section{Random sampling approach}

Continuing the study in the dry season of 2011, we made a $500 \times 500 \mathrm{~m}$ grid centered at the studied stream (Figure $1 \mathrm{D})$, and randomly selected a total of 40 plots measuring $625 \mathrm{~m}^{2}(25 \times 25 \mathrm{~m})$. Each plot was located in the field with aid of a GPS (Map 78S, Garmin, New Taipei City, Taiwan). Within these plots, all adult palms were identified and counted. The four environmental variables considered were "tree basal area", "number of trees" (excluding palm trees) representing forest structure, "altitude", and "distance to the stream" for topography and drainage. Altitude was measured with the GPS at the center of the plot, and varied from 140 to $190 \mathrm{~m}$ above the sea level. The straight distance from the floodplain was measured in the relation to the GPS map of the floodplain limits.

Species abundance and environmental data were also used to produce a biplot of palm species and their environmental correlates using Canonical Correspondence Analysis (CCA). Only palm species with more than 10 individuals were included in the CCA in order to reduce the importance of rare species whose distributions are difficult to explain ecologically and could weaken the overall ordination results (ter Braak 1989). Finally, we tested the effect of distance from a floodplain on palm community composition using Permutational Multivariate Analysis of Variance procedure (PERMANOVA) (Anderson 2001). In our specific case, we used Bray-Curtis (Legendre and Legendre 1998). For this, the distance from the floodplain was grouped into three classes: sites within the floodplain; sites between $1 \mathrm{~m}$ and $50 \mathrm{~m}$ from the floodplain and; sites further than $50 \mathrm{~m}$ from the floodplain.

\section{RESULTS}

The reduced values of tree basal area and the low median diameter of the measured trees indicate the forest's colonization history over the last century, before it became a protected area of the $51^{\text {st }}$ BIS (Table 1). Despite having several scattered areas with very large trees, typical of old growth forests, the $51^{\text {st }} \mathrm{BIS}$ vegetation is generally open, with dense understory.

We counted a total of 11 species within 423 adult palms in the plots regularly distributed and centered at the stream course (Table 2). The most abundant palm species was E. oleracea. This species reached its highest density $\left(345 \pm 37\right.$ palms ha $\left.^{-1}\right)$ on plots located in seasonal floodplains that surrounded the river but decreased in density along the first $100 \mathrm{~m}$ from the stream up to a point where the palms disappeared completely $\left(\mathrm{r}_{\mathrm{s}}=-0.963, p<0.01\right)$. The second most abundant palm species, Attalea phalerata, also exhibited its highest density in the floodplain (42 \pm 9 palms ha $^{-1}$ ) and decreased in density after the floodplain limits within the first $100 \mathrm{~m}$ from the stream,
Table 1. Forest structure based on measured trees with $\mathrm{DBH}, \geq 10 \mathrm{~cm}$ according to the systematic sampling approach (Syst. appr.) and the random sampling approach (Rand. Appr.) at the study site.

\begin{tabular}{|c|c|c|}
\hline Forest structure & Syst. appr. & Rand. appr. \\
\hline Total of measured trees & 942 & 678 \\
\hline Number of trees ha-1 & $235 \pm 67$ & $271 \pm 132$ \\
\hline Basal area $\mathrm{m}^{2} \mathrm{ha}^{-1}$ & $15.7 \pm 7.9$ & $16.7 \pm 11.9$ \\
\hline Median tree diameter & $17.5 \mathrm{~cm}$ & $16.9 \mathrm{~cm}$ \\
\hline
\end{tabular}

Table 2. Abundance of palms (total number of palms and number of palms per hectare) according to the systematic sampling approach (Syst. appr.) and the random sampling approach (Rand. Appr.) at the studied forest.

\begin{tabular}{|c|c|c|c|c|}
\hline \multirow[b]{2}{*}{ Palm species } & \multicolumn{2}{|c|}{ Syst. appr. } & \multicolumn{2}{|c|}{ Rand. appr. } \\
\hline & $\begin{array}{l}\mathrm{N}^{\circ} \text { of } \\
\text { palms }\end{array}$ & $\begin{array}{c}\text { palms } \\
\mathrm{ha}^{-1}\end{array}$ & $\begin{array}{l}\text { No of }^{\circ} \\
\text { palms }\end{array}$ & $\begin{array}{c}\text { palms } \\
\mathrm{ha}^{-1}\end{array}$ \\
\hline Astrocaryum aculeatum G. F. W. Meyer & 11 & 2.7 & 6 & 2.4 \\
\hline Astrocaryum gynacanthum Mart. & 18 & 4.5 & 27 & 10.8 \\
\hline Astrocaryum murumuru Mart. & 4 & 1.0 & 2 & 0.8 \\
\hline Attalea maripa (Aubl.) Mart. & 5 & 1.2 & 12 & 4.8 \\
\hline Attalea phalerata Mart. ex Spreng. & 58 & 13.2 & 10 & 4.0 \\
\hline Bactris acanthocarpa Mart. & 2 & 0.5 & 1 & 0.4 \\
\hline Euterpe oleracea Mart. & 283 & 70.7 & 66 & 26.4 \\
\hline Oenocarpus bataua Mart. & 3 & 0.7 & 0 & 0.0 \\
\hline Oenocarpus distichus Mart. & 2 & 0.5 & 2 & 0.8 \\
\hline Socratea exorrhiza (Mart.) H.Wendl. & 29 & 7.2 & 11 & 4.4 \\
\hline Syagrus cocoides Mart. & 8 & 2.0 & 6 & 2.4 \\
\hline
\end{tabular}

also disappearing completely in areas distant from the stream $\left(r_{s}=-0.632, P=0.025\right)$. Socratea exorrhiza, the third most abundant species, was also positively associated with the stream. It reached a density of $5 \pm 4$ palms ha ${ }^{-1}$ in the floodplain, and increased in abundance in the hilly terra firme areas adjacent to the floodplain $(24 \pm 9$ palms ha-1), also becoming rarer at greater distances from the floodplains $\left(\mathrm{r}_{\mathrm{s}}=-0.791, P=0.003\right)$ (Figure 2a). The next two species in order of abundance, $A$. gynacanthum and $A$. aculeatum, showed an opposite pattern in relation the previous ones in that they were never found in the floodplains (Figure 2B).

The $625 \mathrm{~m}^{2}$ randomly distributed plots had an average of $1.6 \pm 1.0$ palm species. Of the ten palm species found in the randomly distributed plots, only five had at least ten sampled adult individuals (Table 2), and therefore only these five were included in the CCA. Nine plots had no adult palms and were not included in the analysis. The environmental variables explained $33 \%$ of the variability of the palms community structure (Table 3). The main gradient (axis 1) explained $26 \%$ of the variability and it was significantly associated with distances from the floodplains, as well as altitude. The scatter-diagram (Figure 3) shows a clear separation from both the plots that were at least partly affected by seasonal flooding 

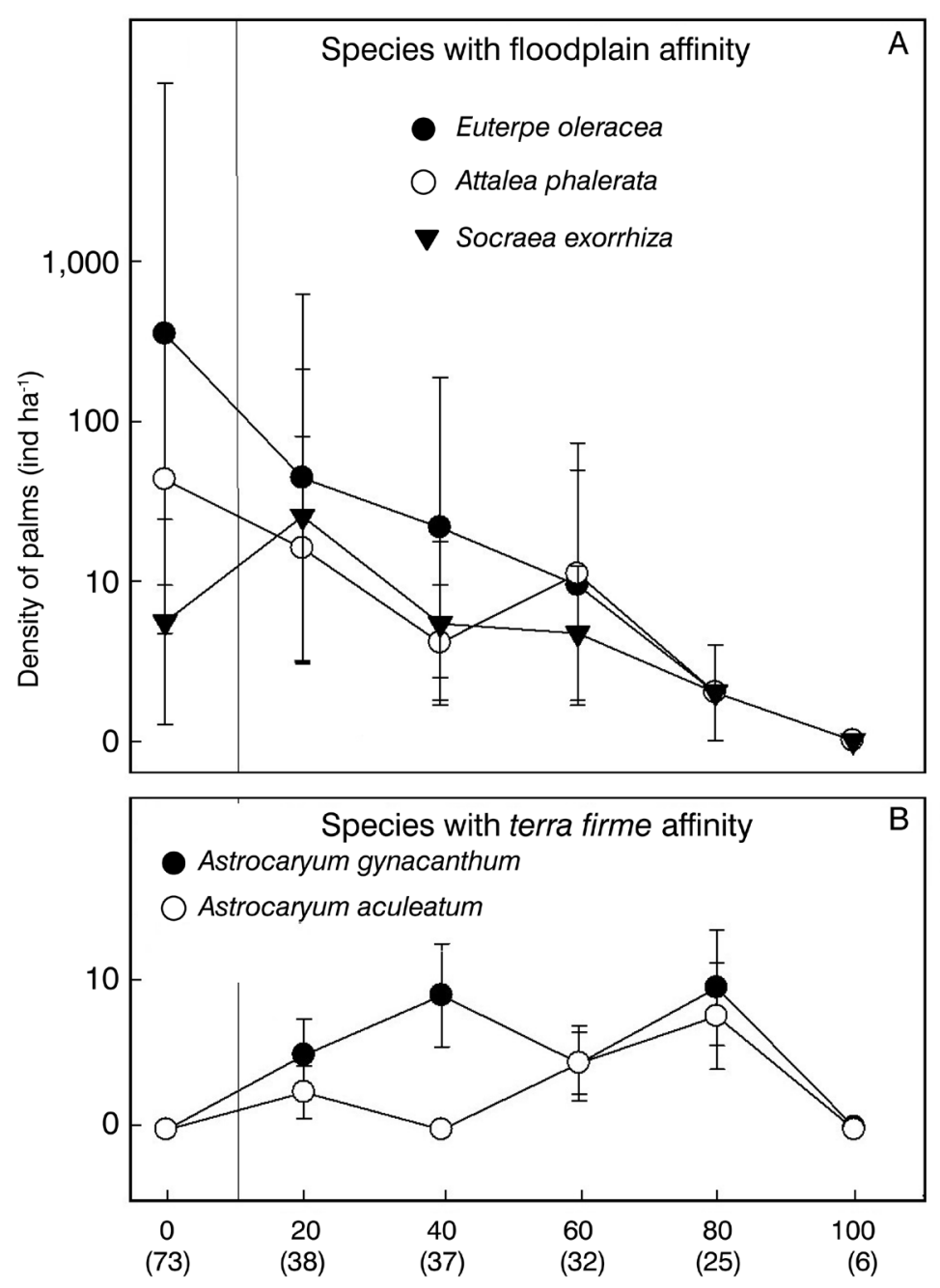

Floodplain

Distance $(m)$ from the floodplain

Figure 2. Abundance of palms in a cross section of the $51^{\text {st }} \mathrm{BIS}$ perennial stream, according to the 20 transects $(200 \times 10 \mathrm{~m})$ centered at the studied perennial stream. A: Species with floodplain affinity: Euterpe oleracea (black circle), Attalea phalerata (white circles) and Socratea exorrhiza (black triangles); B: Species with terra firme affinity: Astrocaryum gynacanthum (black circles) and Astrocaryum aculeatum (white circles). For the sake for clarity, in this figure, the $200 \mathrm{x}$ $10 \mathrm{~m}$ transects were divided in 10 subplots of $20 \times 10 \mathrm{~m}$. Numbers between brackets indicate sample size.

Table 3. Summary of canonical correspondence analysis: partitioning of variance, contribution of the first two axes, and environmental vectors fitted. * Permutation test with p-value $<0.05$.

\begin{tabular}{lcc}
\hline Partitioning of variance & Inertia & Proportion \\
\hline Total & 2.13 & 1.000 \\
Constrained & 0.71 & $33 \%$ \\
Unconstrained & 1.42 & $67 \%$ \\
Contribution of the first two axes & Axis 1 & Axis 2 \\
Eigenvalue & $0.562^{\star}$ & 0.115 \\
Proportion Explained & 26.4 & 5.3 \\
Cumulative Proportion & 26.4 & 31.7 \\
\hline
\end{tabular}

as well as those located more than $50 \mathrm{~m}$ from the floodplains (PERMANOVA, pseudo-F= 5.87; $P=0.001$ ). The other plots between these areas were spread between these two separated groups. The two most abundant palm species, E. oleracea and A. gynacanthum, showed radically divergent positions in the scatterplot along CCA Axis 1, the first being associated with the floodplains (lowest altitudes and close to the floodplains), and the second being associated with terra firme plots (highest altitudes and far from the floodplains). Likewise, $A$. phalerata was associated with the seasonally-flooded plots and low altitudes, while $A$. maripa was related to terra firme plots at larger distances from the floodplains. Finally, S. exorrhiza was also positively associated with the floodable plots (Figure 3). 


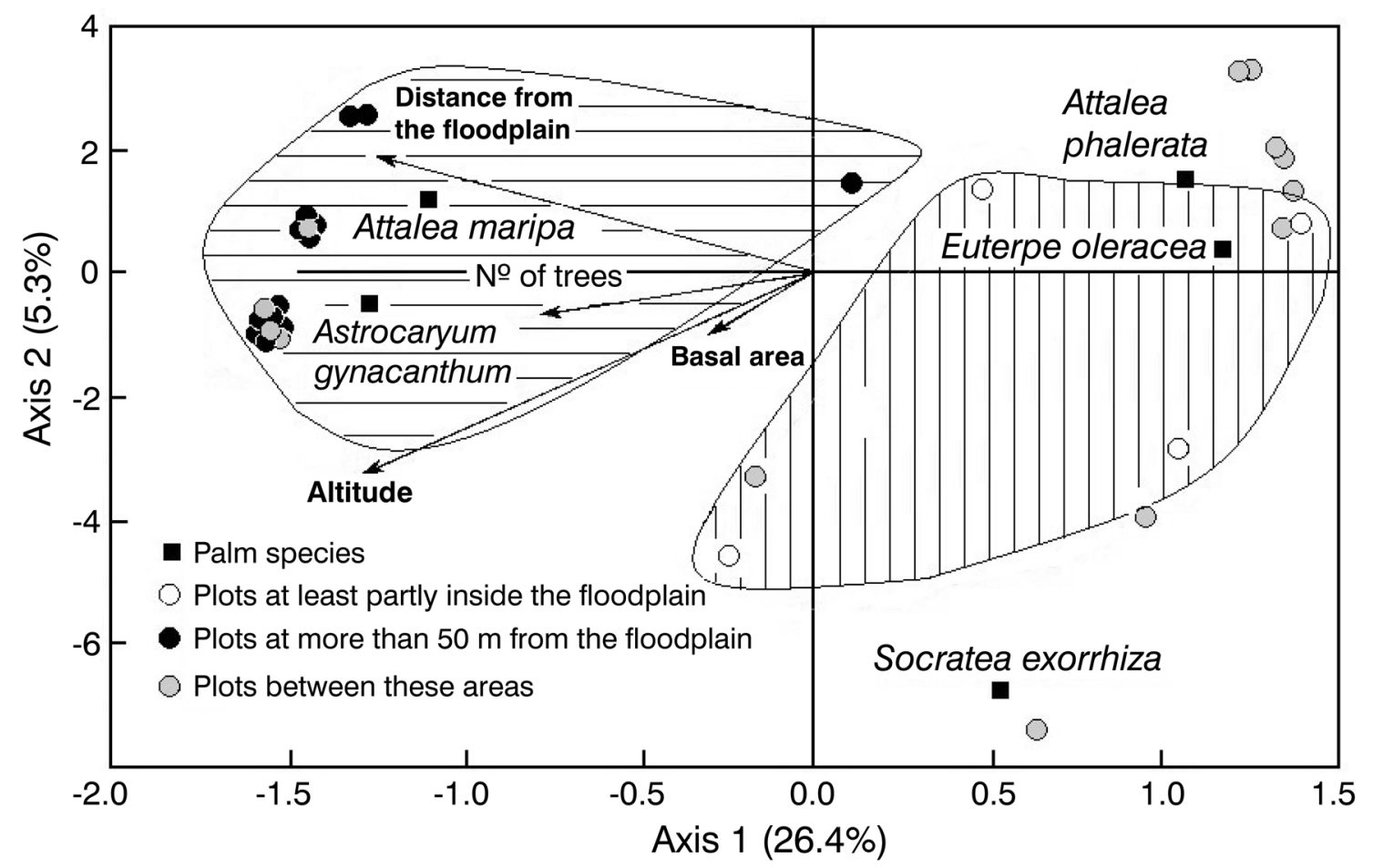

Figure 3. Canonical Correspondence Analysis (CCA) ordination showing the scores of principal axes of 5 palms species (black squares) overlapping with those of 40 plots of $625 \mathrm{~m}^{2}(25 \times 25 \mathrm{~m})$ spread in a $500 \times 500 \mathrm{~m}$ area around the $51^{\text {st }}$ BIS Stream, along with environmental factors. The vertically lined area represent the plots that are at least partly inside the floodplain (white circles) around the stream, where the horizontally lined area represent the plots $\geq 50 \mathrm{~m}$ from the floodplain (black circles). The plots in between these areas are represented in grey.

\section{DISCUSSION}

The clear niche segregation pattern within the palm community along the topographic gradient of the $51^{\text {st }}$ BIS forests is well documented for other sites. Therefore, palm ecologists are now facing the challenge of moving to more specific questions like the behavior of individual species across different sites. Unfortunately, descriptions of palm communities are extremely patchy in the Amazon (Balslev et al. 2010) in relation to species ranges. For that reason, the results of this study may only be compared to one other palm community study made on the Xingu river basin 500 $\mathrm{km}$ south (Salm et al. 2007), and to two other studies that are geographically closest: one is $300 \mathrm{~km}$ to the east (Kahn 1987 ) and the other is $350 \mathrm{~km}$ southeast (Scariot et al. 1989). Both are in the Tocantins River basin. Taking the results of our two complementary approaches to the study of the $51^{\text {st }}$ BIS forest palm community into account, we created an illustrated description (Figure 4A, B) ranking the six most abundant palm species transitions along the floodplain- terra firme gradient in our study site, in which the studied palm species were organized from the most flood tolerant to those found at greater distances of the stream. The strong association of E. oleracea to the floodplains is welldocumented (Henderson et al. 1995). It is a predominant species in the palm forests of the Amazon estuary floodplains, dominating an area of more than $10,000 \mathrm{~km}^{2}$ (Anderson 1988). It was described as a "hyperdominant" species, the 6th in abundance in the Amazonian tree flora (ter Steege et al. 2013). Nevertheless, few studies document the transition of this species distribution from floodplain to terra fime forests. We found that this species presents a gradual decline in abundance over the first one hundred meters from the floodplain before disappearing completely. Svenning (1999) found that several species among a palm community in the Amazonian Ecuador, that showed preferences to a particular topographic position also occurred in the least preferred topographic position. He attributed their persistence in these least preferred areas to continuous seed dispersal from the preferred habitat. A similar process may explain the gradual decline in abundance of this species at greater distances of the floodplain at the $51^{\text {st }}$ BIS forest. Scariot et al. (1989) also observed lower densities of individuals of E. oleracea at growing distances to the stream, but the rate of the decline was lower than what we observed in our study site. Indeed, the difference in altitude measured by Scariot et al. (1989) 


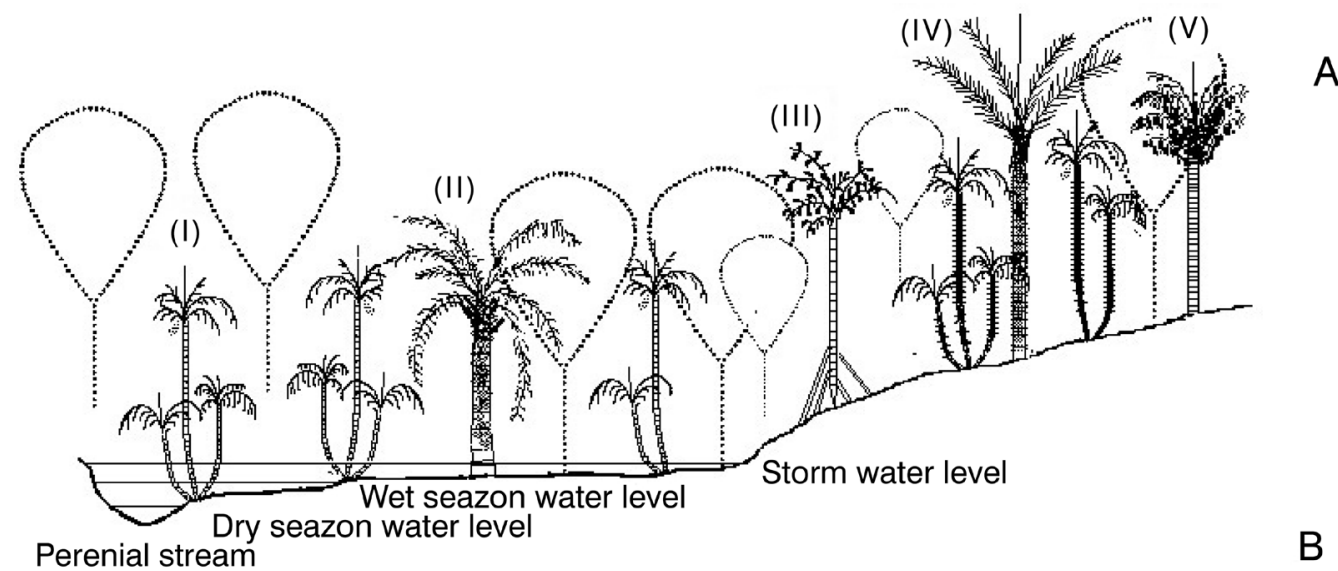

Perenial stream

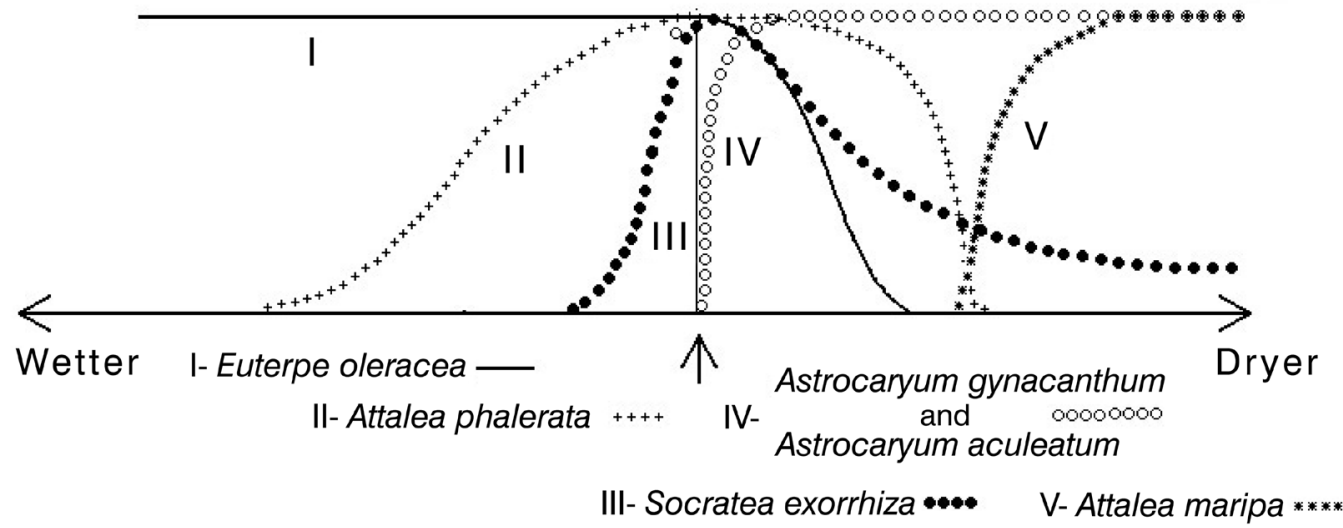

Figure 4. Palm community transitions along a floodplain- terra firme topographic gradient from the most flood-tolerant to those found at greater distances of the stream, in the Xingu river basin. A: Pictorial description of the six most abundant palm species (those that had $\geq 10$ individuals in at least one of the adopted two sampling approaches) in relation to water level. B: Approximate abundance curves of the species distribution, based on the obtained results, in relation to humidity. Vertical lines represent the limit between floodable and terra firme forests.

in the Tocantins valley was also substantially shorter than the difference that we found in the $51^{\text {st }}$ BIS forest. The palm $E$. oleracea was rare in the study by Kahn (1987), and was not found in the other studied site southward in the Xingu basin (Salm et al. 2007), where it is replaced by Euterpe precatoria.

Attalea phalerata, the next species in our rank of association was not documented in any of the three other nearest study sites (Kahn 1987; Scariot et al. 1989; Salm et al. 2007), despite its wide distribution in the southern limits of the Amazon (Henderson et al. 1995). It is very abundant in the Pantanal-Matogrossense, the world's largest floodplain, where it occurs in both alluvial and periodically flooded soils, and islands of woody vegetation a few meters above the floodable areas (Henderson et al. 1995). It is remarkable that in the $51^{\text {st }}$ BIS forest, this species is restricted to the floodplains and its proximities, since it usually grows well, although at lower densities, over dry soils (Normand et al. 2006). The cooccurrence of the congeneric species $A$. maripa in our site may explain this pattern, in part. Our results show a clear ecosystem partitioning between these palms with $A$. phalerata associated with the floodplains and $A$. maripa with terra firme forests (Figure 3). The palm A. maripa, is relatively rare at the $51^{\text {st }} \mathrm{BIS}$ forest when compared to the studied palm community further south in the Xingu basin where it is five times more abundant (Salm et al. 2007). Therefore, it is hard to believe that direct competition between these two species of Attalea may push A. phalerata toward the floodplain area. We hypothesize that "apparent competition", defined by Holt (1977) as an indirect interaction consequent of a generalist predator over alternate prey species may be responsible for the observed clear-cut ecosystem segregation between these palms. The bruchid beetle Pachymerus cardo is an important seed predation of both $A$. maripa (Fragoso and Silvius 2003; Salm 2006) and A. phalerata (Quiroga-Castro and Roldan 2001; Rios and Pacheco 2006). Due to its disproportionally harmful effect over the rarest of the indirectly competing species, this seed predator may cause the exclusion of one species or another from a given habitat. The most common species of large tall- 
stemmed palms among palm communities' inventories in the Amazon (Balslev et al. 2011), A. maripa, dominates the terra firme forests of the $51^{\text {st }} \mathrm{BIS}$, while $A$. phalerata resists and excludes $A$. maripa from the proximities of the floodplain due to its higher tolerance to flooding (Henderson et al. 1995). Similarly, the two sympatric Attalea species, A. attaleoides and A. microcarpa are locally segregated in the terra firme forest close to Manaus, $A$. attaleoides occurs more often on upland plateaus, whereas $A$. microcarpa is confined to bottomlands (Costa et al. 2009). Freitas et al. (2012) investigated and found no evidence that seed removal or seed germination patterns in relation to topography or abundance of adults explained the topographic separation between the two species. It is possible that seed predation intermediated by a shared predator may also explain such a division.

Socratea exorrhiza, the third palm species in our proposed rank of association at the $51^{\text {st }} \mathrm{BIS}$ forest is also a hyperdominant species, the $9^{\text {th }}$ most abundant tree in the Amazonian flora (ter Steege et al. 2013). Within our studied palm community, it is the species with the largest distribution area across the Amazon basin and Central America (Henderson et al. 1995). Although mainly concentrated close to the floodplain, S. exorrhiza was not abundant in the floodable areas, but rather in steep terrains at the stream edges. Scariot et al. (1989) also found that $S$. exorrhiza was more abundant close to the water and characterized its distribution in the forest as limited to "fairly humid, well-lighted margins of watercourses, and gaps in the wetter portions of the forest." Kahn (1987) did not register the species. In a subsequent study $S$. exorrhiza was also associated with moist sediments in the Peruvian Amazon (Normand et al. 2006). Svenning (1999) also found that S. exorrhiza was much more abundant close to the Tiputini floodplain in Ecuador and suggested that it was maintained in the terra firme by seed dispersal from that habitat.

Finally, A. gynacanthum and A. aculeatum were absent from the floodplains of our studied area and elsewhere across their distribution (Henderson et al. 1995; Lorenzi et al. 2010). A. gynacanthum was abundant and more frequently found towards terra firme forests in three other of the nearest studied palm communities (Kahn 1987; Scariot et al. 1989; Salm et al. 2007). Astrocaryum aculeatum also rarely occurs in lowland rainforests (Henderson et al. 1995). We encountered the much rarer Astrocarym murumuru, in very low densities associated with the floodplains of the $51^{\text {st }}$ BIS forest. This species was listed as one of the most abundant $\left(10^{\text {th }}\right)$ tree species in the Amazonian flora (ter Steege et al. 2013). It is found along river margins and other periodically flooded areas at low elevations across most of the Amazon basin (Henderson et al. 1995), and it is abundant in periodically flooded alluvial soils of the western Amazon (Kahn and Mejia 1990).
Our study site in the eastern Amazon has a palm species diversity (11 species) lower than the median (16 species) and much poorer than terra firme sites of the western Amazon, probably due to our seasonal dryer climate (Balslev et al. 2011; Eiserhardt et al. 2012). It is also characterized by a high percentage of palm species (63\%) and individuals (88\%), belonging to the category of large tall-stemmed palms. The percentage of caespitose species is low (27\%) compared to all habitat types categorized by Balslev et al. (2011), but these palms correspond to $70 \%$ of the adult individuals. There is a noticeable general poverty of small palms, both in number of species and of individuals compared the general patterns across the Amazon (Balslev et al. 2011). Current palm-species distributions and diversity patterns depend not only on the contemporary environment, but also on past events, including historical effects at finer spatial scales (Eiserhardt et al. 2012). Our interpretation is hindered by the fact that there is no information on the forest structure prior to one hundred years ago, when the area was first colonized by non-Amerindians.

There is a large gap in the knowledge about Amazonian palms communities including the Big Bend of the Xingu River, hundreds of kilometers wide (Balslev et al. 2011). This moment is especially important for such studies because of the rapid deforestation due to colonization and megainfrastructure building in this area (Fearnside 2006). By studying the transitions in palm species composition along the gradient from the $51^{\text {st }}$ BIS forest stream we intended to contribute to a limited understanding of individual species behavior. We understand that the interpretation of these patterns is still tentative but by discussing such possibilities, we expect to stimulate further research about these various aspects of palm ecology.

\section{ACKNOWLEDGEMENTS}

We would like to thank the students Maria do Céu and Cleber Soares Sousa for their assistance with fieldwork. We are deeply thankful to anonymous reviewers for essential comments on the manuscript. The authors also thank the Brazilian Army, specifically the $51^{\text {st }}$ Forest Infantry Battalion $\left(51^{\text {st }} \mathrm{BIS}\right)$ for authorization to develop this study within their area, and for their logistical support. We are also thankful to the Federal University of Pará (UFPA) for financial support (Financial and Technical Cooperation Agreement $n^{\circ}$ 017/2010 - UFPA/FAPESPA).

\section{REFERENCES}

Anderson, A.B. 1988. Use and management of native forests dominated by açaí palm (Euterpe oleracea Mart.) in the Amazon estuary. Advances in Economic Botany, 6: 144-154.

Anderson, M.J. 2001. A new method for non-parametric multivariate analysis of variance. Austral Ecology, 26: 32-46. 
Balslev, H.; Eiserhardt, W.; Kristiansen, T.; Pedersen, D.; Grandez, C. 2010. Palms and Palm Communities in the Upper Ucayali River Valley - a Little-Known Region in the Amazon Basin. Palms, 54: 57-72.

Balslev, H.; Kahn, F.; Millan, B.; Svenning, J.C. Kristiansen, T.; Borchsenius, F.; Pedersen, D.; Eiserhardt, W. 2011. Species Diversity and Growth Forms in Tropical American Palm Communities. The Botanical Review, 77:381-425.

Costa, F.R.C.; Guillaumet, J.L.; Lima, A.P.; Pereira, O. 2009. Gradients within gradients: The mesoscale distribution patterns of palms in a central Amazonian forest. Journal of Vegetation Science, 20: 69-78.

Eiserhardt, W.L.; Svenning, J.C; Borchsenius, F.; Kristiansen, T.; Balslev, H. 2012. Separating environmental and geographical determinants of phylogenetic community structure in Amazonian palms (Arecaceae). Botanical Journal of the Linnean Society, 171: 244-259.

Fearnside, P.M. 2006. Dams in the Amazon: Belo Monte and Brazil's Hydroelectric Development of the Xingu River Basin. Environmental Management, 38: 16-27.

Fragoso, J.M.V.; Silvius, K.M. 2003. Long-distance seed dispersal by tapirs increases seed survival and aggregates tropical trees. Ecology, 84: 1998-2006.

Freitas, C.G.; Costa, F.R.C.; Svenning, J.C.; Balslev, H. 2012. Topographic separation of two sympatric palms in the central Amazon - does dispersal play a role? Acta Oecologica, 39: 128-15.

Henderson, A.; Galeano, G.; Bernal, R. 1995. Field Guide to the Palms of the Americas. Princeton University Press, Princeton, New Jersey. 353 p.

Holt, R. D. 1977. Predation, apparent competition and the structure of prey communities. Theoretical Population Biology, 12: 197-229.

Kahn, F.; Castro, A. 1985. The palm community in a forest of Central Amazonia, Brazil. Biotropica, 20: 266-269.

Kahn, F. 1987. The distribution of palms as a function of local topography in Amazonian terra-firme forests. Experientia, 43: 251-259.

Kahn, F.; Mejia, K. 1990. Palm communities in wetland forest ecosystems of Peruvian Amazonia. Forest Ecology and Management, 33: 169-179.

Kahn, F.; de Granville, J. 1992. Palms in forest ecosystems of Amazonia. Springer Verlag, New York. 226 p.
Legendre, P.; Legendre, L. 1998. Numerical ecology. Elsevier Science, Oxford, UK. 852 p.

Lorenzi, H.; Noblick, L.R.; Kahn, F.; Ferreira, E. 2010. Flora Brasileira - Arecaceae (Palmeiras). Instituto Plantarum, Nova Odessa, SP, 384 p.

Lucas, E.W.M.; Sousa, F.A.S.; Silva, F.D.S.; Lucio, P.S. 2009. Modelagem hidrológica determinística e estocástica aplicada à região hidrográfica do Xingu- Pará. Revista Brasileira de Meteorologia, 24:308-322.

Normand, S.; Vormisto, J.; Svenning, J.-C.; Grández, C.; Balslev, H. 2006. Geographical and environmental controls of palm beta diversity in paleo-riverine terrace forests in Amazonian Peru. Plant Ecology, 186: 161-176.

Peres, C.A. 1994. Composition, density, and fruiting phenology of arborescent palms in an Amazon terra firme forest. Biotropica, 26: 285-294.

Quiroga-Castro, V.D.; Roldán, A.L. 2001. The fate of Attalea phalerata (Palmae) seeds dispersed to a tapir latrine. Biotropica, 33: 472-477.

Rios, R.S.; Pacheco, L.F. 2006. The Effect of Dung and Dispersal on Postdispersal Seed Predation of Attalea phalerata (Arecaceae) by Bruchid Beetles. Biotropica, 38: 778-781.

Salm, R. 2006. Invertebrate and Vertebrate Seed Predation in the Amazonian Palm Attalea maripa. Biotropica, 38: 558-560.

Salm, R.; Salles, N.V.; Alonso, W.J.; Schuck-Paim, C. 2007. Crossscale determinants of palm species distribution. Acta Amazonica, 37: 17-26.

Scariot, A.O.; Oliveira Filho, A.T.; Lleras, E. 1989. Species richness, density and distribution of palms in an eastern Amazonian seasonally flooded forest. Principes, 33: 172-179.

Svenning, J.C. 1999. Microhabitat specialization in a species-rich palm community in Amazonian Ecuador. Journal of Ecology, 87: 55-65.

ter Braak, C.J.F. 1989. CANOCO — an extension of DECORANA to analyze species-environment relationships. Hydrobiologia, 8: $169-170$

ter Steege, H.; Pitman, N.C.A.; Sabatier, D.; Baraloto, C.; Salomão, R.P.; Ernesto Guevara, J.; et al. 2013. Hyperdominance in the Amazonian tree flora. Science, 342: 325-334.

Recebido em 10/04/2014

Aceito em 21/07/2014 
